\title{
Integrating Linguistic Diversity in Globalized Spanglish Communities
}

\author{
Marina Yu. Semenova* \\ Don State Technical University, Department of Scientific and Technical Translation and Professional Communication, 344000 \\ Rostov-on-Don, Russia
}

\begin{abstract}
Globalization comprises a complex range of various processes and has a huge impact on many spheres of life, including languages and dialects. The paper analyzes linguistic phenomena caused by globalization which have resulted in a new language type which can be denoted as 'poststandard languages'. English being a means of international communication has entered many standard language systems causing an extensive use of English loanwords and pseudo-English elements combined with a wordplay. This anglicalization results in two or more languages merging into a new poststandard language, a common means of communication in a multilingual diverse society. One of the most vivid examples is Spanglish, an English-Spanish merge in the USA and Latin America. It is characterized by a high degree of substrata merging and diversity levelling. Thus the article analyzes the identity of Spanglish speakers as well as linguistic features and functions of such 'Glishes' which differentiate them from standard English and Spanish.
\end{abstract}

\section{Introduction}

Globalization is considered one of the main interdisciplinary subjects of current research and is ultimately reflected through the language. Consequently, it results in a new linguistic formation which can be denoted as poststandard, with modern standard languages being their source and/or substrata.

This paper discusses the multilingual heterogeneous situation in the USA and Latin America caused by an extensive spread of bilingualism. This has raised certain concerns among linguists as they witness the process of diversification of the American society. At the same time globalization has triggered the mechanism of integrating the society through a new poststandard language variety called Spanglish.

So the article also attempts to review the case of Spanglish (a merge of English and Spanish in the USA and Latin America) as the most vivid illustration of innovative linguistic features and functions caused by and aiming to change the deformed and prejudiced attitude which discriminates the Spanish-speaking community of the above-mentioned geographical region.

\section{Language standardization and poststandardization}

\subsection{Language standardization}

The language standardization is closely connected to the technological advance and education. The main stages of standardization in English were interlinked with the technical progress because new printing and publishing technologies required unified linguistic norms, which, is their turn, should be based on distinguished functional styles [1]. Another important factor was the development of English educational system and the increased number of educational institutions where various types of reference material and books were needed. In this respect it can be stated that the conventional print standard of a language became universal and widespread, which facilitated language use in many social and cultural contexts [2].

The end of the World War II saw the emergence of a new and versatile phenomenon - globalization. Economic globalization was the first to be seen and it was enhanced by the rising number of transnational companies using human resources and the quality of service as their competitive advantage. The $20^{\text {th }}$ century also witnessed new types of communication means such as television, the Internet, emails, mobile phones (including text messages) and, most recently, social network sites and Twitter. Today, alongside with empirical evidence, there is a strong scientific ground to prove that English language use is a strong motivating factor of business and political success [3].

The above-mentioned global tendencies have brought about a new stage of the language evolution among all world languages which are in a close contact with English. In addition, T. McArthur mentioned that, "Standard English is an haute cuisine lingua franca if there was one. But whose Standard English, and what in any case constitutes the standard for a language whose

* Corresponding author: semenova.marina.yu@yandex.ru 
users are counted in hundreds of millions worldwide (however uncertain in the total). $<_{\ldots} .>$ 'traditional' Standard Englishes co-exist with many other Englishes.” [2].

\subsection{Language poststandardization}

It turns out to be the same with all other languages nowadays, which can be represented in a number of new linguistic varieties listed in the form of an English-based classification:

- global English, which is the public international language used by non-English speakers;

- international English, which is studied as a lingua franca throughout the world and often taken as a whole (opposed to the dialects of English);

- world Englishes, which comprise all the varieties (standard, dialect, national, regional, creole, hybrid, 'broken', etc.).

These English language varieties contacting with many other languages bring to life new linguistic phenomena. But the degree of contact can be different [4]:

- casual contact characterized by lexical borrowing and limited to content words;

- slightly more intense contact when some function words and auxiliaries are borrowed;

- more intense contact when structural wordbuilding pattern borrowing and can be seen;

- very strong cultural pressure when the language structure is significantly changed and words comprise morphemes of different origin follow new patterns of wordbuilding.

In case of intense contact and cultural pressure, the impact of globalization is so multilateral that it ultimately results in four basic linguistic representations. This fact formulates the idea of a new era of global language development perspective, which can be called poststandard and is generally characterized by:

- regionalization of international languages, which leads to new dialects and sociolects;

- neutralization of lingua francas, which presupposes the loss of connotative meanings, due to increased immigration and business internationalization;

- extensive use of play of words, pseudo loan-words and hypertext techniques, which is characteristic of postmodern texts;

- merge of contacting languages, which is based on constant code-switching and code-mixing, develops new communicative strategies and can be viewed as a new language variety [5].

Accordingly, a poststandard language can be defined as a new linguistic variety resulting from a language contact (in a bilingual or multilingual community), spoken by descendants of immigrants, and aiming at integrating people of different cultural and social background into the more or less unified community of their country.

One of the most vivid examples of this new language variety is Spanglish, an English-Spanish merge and a popular means of communication in the USA and Latin
America. Other examples are Runglish, Chinglish, Franglais, etc. Today 22 poststandard languages have been registered, all of them characterized by a high degree of substrata merging and diversity levelling.

The spread of Spanglish has already been linked to certain alarmist opinions which provoke future discussions among journalists, academics, writers and the general public, both English- and Spanish speaking.

Although the status of Spanglish and other related phenomena is quite controversial, Spanglish texts define a new identity and a new way to communicate in a multilingual community:

(1) "See, it's alive," he said, and right that minute, at a window next door to us, a woman yelled to her son down on the street. "Mira, Juanito, go buy un mapo, un contén de leche, and tell el bodeguero yo le pago next Friday. And I don't want to see you in el rufo!" $<\ldots>$

('Look, Juanito, go buy a mop, a carton of milk and tell the grocer I'll pay him next Friday. And I don't want to see you on the roof!')

"You know what is happening here, don't you? Don't you? What we just heard was a poem, Chino. It's a beautiful new language. Don't you see what's happening? A new language means a new race. Spanglish is the future. It's a new language being born out of the ashes of two cultures clashing with each other. You will use a new language. Words they might not teach you in that college. Words that aren't English or Spanish but at the same time are both. Now that's where it's at. Our people are evolving into something completely new." (Quiñones).

In (1) above, one can see a clear demonstration of a clash of two cultures and languages resulting in an absolutely innovative linguistic phenomenon breaking historical, social and political borders ("a new language born out of the ashes of two cultures", "Words they might not teach you in that college.").

Á. López García-Molins observes that Spanglish should be a process of linguistic convergence from Spanish to English, and notes that this usually happens in the second generation Spanish-speaking citizens of the USA [6]. Quite interestingly, the same might happen to a native English speaker switching into Spanish-language communication to coincide in the cross-cultural context. More importantly, Spanglish is not considered a creole language because it is a hybrid combination which follows structural conditions defined by both substrata languages, which will be discussed in the next section. So it can be rather viewed as a result of a neurolinguistic cross of two languages.

S. Betti argues that Spanglish has fallen a victim of prejudice on behalf of many scholars who consider it a threat to conventional theories and diminish its social, cultural, emotional, psychological, and pragmatic functions that shape verbal behavior of its speakers [7].

Thus we can sum up that Spanglish as a poststandard language tends to be used to form a new in-between identity of American bilinguals aiming at creating a new linguistic environment which can convey new meanings and symbols. 


\section{Spanglish as an English-Spanish merge: a new language type and a new identity}

\subsection{Definitions of Spanglish}

The United States of America and bordering Latin American countries is a multiethnic geographical region, which integrates people of different social background and is characterized by a high level of multilingualism. English and Spanish, which are the most popular languages in the area, tend to reflect the complicated political and social issues regarding the Latinos in the USA. This complexity provokes a heated debate on the status of Spanglish (or Chicano English as it is sometimes called by American linguists): "whether it is an epiphenomenon of language contact or an autonomous dialect" [8].

Spanglish allows us to witness how globalization shapes a new language variety, which cannot be referred to as a dialect of English or Spanish due to the fact that, according to G. Tottie, "[Spanglish] has developed stable speech patterns and a distinct phonological system of its own, with several features that cannot be due to interference from Spanish" [9].

Traditionally, there is a set of five criteria for a language code to be classified as a distinct linguistic variety:

- there should be "[a] standard and recognizable pattern of pronunciation handed down from one generation to another" [10];

- there should be certain lexical and idiomatic elements, which are peculiar to the variety and can be used to express key concepts;

- the history of the language community tends to create and stabilize the given variety;

- there should be fiction texts written in that variety;

- there should be dictionaries and other databases to demonstrate how the speakers identify themselves and their language.

Spanglish seems to meet all the above mentioned criteria

First, it certainly has a distinctive pronunciation and spelling which is recognizable and cannot be confused with English or Spanish grapho-phonetical features.

Second, it has a considerable number of its own elements which are not borrowings or calques.

Third, the history of the Latin community in the USA is long enough to show how peculiar traditions and customs have been formed inside it and how its members are different from those of other communities.

Fourth, today the USA and Latin American countries are famous for both poetic and prosaic texts written in Spanglish (e.g., Boricua poets, Giannina Braschi's novels, pop songs by Ricky Martin, Jennifer Lopez, etc.) as well as translations of some prominent literary works from other languages (e.g., Don Quixote de la Mancha by Miguel Cervantes de Saavedra).

Finally, there have been publications which can be regarded as examples of Spanglish dictionaries and other types of reference material. Ilan Stavans was the first scholar to state that Spanglish should be considered a new separate language [11]. At the same time, B. Cruz and B. Teck compiled the first dictionaries featuring Spanglish as such [12].

Moreover, Spanglish has become a popular language of mass media. In the present-day United States and bordering Latin American countries there are comedy shows conducted by Spanglish speakers like George Lopez and Cheech Marin. These celebrities are wellrespected in their community and their work is mainly based on satire, mockery and criticism.

Quite expectedly, there is no unified definition of Spanglish. For example, E. Morales calls Spanglish a hybrid language, and regards it as an informal code and as a border between two identities in the USA [13]. He believes that Spanglish speakers have two different identities. I. Stavans considers Spanglish to be a mixture of Spanish and English. According to his theory, codeswitching is the most visible characteristics of this language variety [14]. Moreover, this feature of Spanglish triggers the formation of its own varieties just as other languages. Such varieties depend on social and ethnic background and vary in structure and elements. One of the most vivid examples is Tijuana in California, where Spanglish is so common that, when they were renewing trolley tracks in April 2015, a new MTS sign was introduced:

(2) Stops Relocated / Paradas Relocadas.

In (2), the word "relocadas" does not exist in Spanish. If it still did, the sign would mean that "the bus stops are extra crazy" (which would be derived from the Spanish adjective "loco" meaning "mad", "crazy").

Other linguists, on the contrary, do not believe that Spanglish is a language. They tend to view it as a dialect or sociolect of English or Spanish [15]. This position can be argued as it is quite obvious that one and the same language variety cannot be a dialect of two distinctive languages.

Finally, the majority of linguists tend to identify Spanglish as potentially "a frame of mind" [16], and the idea of Spanglish as a language variety used to denote the existential dilemma of the US population is highly encouraged in many contemporary works.

\subsection{Linguistic features of Spanglish}

Spanglish has been developing as a language variety for more than a century. It has worked out its own features which can be used as its visible and clear manifestations.

Basically all the features fall into four main categories:

- graphophonology,

- morpheme structure and wordbuilding patterns,

- vocabulary,

- grammar, encompassing morphology and syntax.

The main phonological characteristics of Spanglish can be summarized as follows:

- reduction of diphthongs to glides, and further reduction to a monophthong (e.g., in the word "sale");

- less vowel reduction in unstressed syllables (e.g., in the word "together": [u:] instead of the schwa); 
- reduction of consonant clusters and visible syncope (e.g., "It's kind of hard." [is 'kenə har]);

- aspiration loss in [p], [t], [k];

- new intonation patterns and syllable-timed prosodies.

Wordbuilding patterns experience two main tendencies:

- frequent examples of verb-formation using suffixes -ar, -er, -ir. E.g.: "e-mailear" ("to email'); "printear" ('to print'); "deletear" ('to delete'); "chequear" ('to check'); "vaquear" ('[to] vacuum clean'), etc.;

- extensive conversion-based patterns. E.g.: "Centro Journal" ('Central Journal'); "spanglish to matao what $\mathbf{i}$ digo" ('Spanglish to kill what I say'); "Laviera feeds the hungry barrio culture" ('Laviera feeds the hungry borough culture'); "un mano-a-mano" ('a competition'), etc.

Lexical and idiomatic features of Spanglish are rather versatile and can be illustrated by the following lexical units of the Spanglish origin: "puertorro" ('a Puerto Rican'); "AO" ('belonging to the Spanglish community'); "anafre" ('a street vendor'), "lo lei lo lai" ('being born in a Spanglish community"); "mocho" ('a person mixing English and Spanish, but not speaking Spanglish'); "pocho" ('a Spanglish speaker').

Other idiomatic features of Spanglish can appear to be based on English or Spanish sources as shown in the table below.

Table 1. Idiomatic features of Spanglish compared to Spanish and English.

\begin{tabular}{|c|c|c|c|}
\hline \multirow[b]{2}{*}{ No. } & \multicolumn{3}{|c|}{ Language } \\
\hline & $\begin{array}{l}\text { Spanish } \\
\text { (source) }\end{array}$ & Spanglish & English \\
\hline 1. & $\begin{array}{l}\text { No me importa } \\
\text { un pito. }\end{array}$ & $\begin{array}{l}\text { I don't care a } \\
\text { whistle. }\end{array}$ & $\begin{array}{l}\text { I don't care at } \\
\text { all. }\end{array}$ \\
\hline 2. & $\begin{array}{l}\text { Me importa } \\
\text { tres pepinos. }\end{array}$ & $\begin{array}{l}\text { I care three } \\
\text { cucumbers. }\end{array}$ & $\begin{array}{l}\text { I don't care at } \\
\text { all. }\end{array}$ \\
\hline 3. & $\begin{array}{l}\text { Ma sacaron el } \\
\text { hígado. }\end{array}$ & $\begin{array}{l}\text { They took my } \\
\text { liver out. }\end{array}$ & $\begin{array}{l}\text { I worked like a } \\
\text { slave. }\end{array}$ \\
\hline 4. & $\begin{array}{l}\text { Tú no pintas } \\
\text { nada. }\end{array}$ & $\begin{array}{l}\text { You don't } \\
\text { paint anything. }\end{array}$ & $\begin{array}{l}\text { This doesn't } \\
\text { concern you. }\end{array}$ \\
\hline
\end{tabular}

The main grammatical feature of Spanglish is codeswitching and code-mixing. J. J. Gumperz defines a code switch as "the juxtaposition within the same speech exchange of passages belonging to two different grammatical systems or subsystems" [17]. Switches occur when morphemes from two or more languages are used together. Alternatively, it may take place when effects of one language over another in the same discourse are observed at the structural level. This phenomenon can be classified into code-switching, which occurs between sentences and thus is called intersentential; and code-mixing, which occurs within one sentence and thus is intrasentential.

Most common patterns that occur in code-mixing are the following:

- insertion of material from one language into the structure of another. E.g.: "Este jaiwei es peligroso." ('This highway is dangerous.');
- alternation between structures. E.g.: "I mean cuando voy al pueblo a comprar algo, I don't like..." ('I mean, when I go to town buy something, I don't like...');

- congruent lexicalization of material from different inventories into a shared grammatical structure. E.g.: "The water esta boileando." ('The water is boiling.');

- equivalent constraint, the order of the elements in a sentence especially if word order is shared. E.g.: "It's a wonderful holiday tradición ... with the familia." ('It's a wonderful holiday tradition ... with the family.').

Sometimes there is a popular misconception that a Spanish or English speaker can easily understand and/or create a Spanglish text. But in most cases it turns out to be quite opposite. For instance, the following piece of a recorded informal social interaction in a group of bilingual adolescents can illustrate this idea [18]:

- Spanglish (source text):

Yo llegué y me bajé de la troka y abrí la traila... y fuimos a arreglar una chimenay que estaba liqueando... luego nos vamos al lonche. Otro día fuimos al mol de Americas y cuando llegué me eché un chagüer.

- Translation into English:

I arrived and got out of the truck and opened the trailer... and we went to fix a chimney that was leaking... then we go to lunch. Another day we went to the Mall of the Americas and when I arrived, I took a shower.

- Translation into Spanish:

Llegué y me bajé de la camioneta y abrí el remolque... y fuimos a arreglar una chimenea que estaba perdiendo... luego fuimos a almorzar. Otro día fuimos al Centro comercial de las Américas y cuando llegué me di una ducha.

It becomes clear enough that the task is impossible. It proves the above-mentioned conception of Spanglish being a merged language and a new frame for a new identity. The following element marking in the example below demonstrates the complexity of blends which constitute Spanglish and make it a peculiar language variety which should be learned to be understood and spoken. So, regular font stands for Spanish, italics is used for Spanglish, and bold type denotes English:

(3) Yo llegué y me bajé de la troka y abrí la traila...y fuimos a arreglar una chimenay que estaba liqueando .....luego nos vamos al lonche. Otro día fuimos al mol de Americas y cuando llegué me eché un chagüer...

In (3), one can notice three extraordinary tendencies: - an extensive use of code-switching between the two languages, sometimes taking place right inside an idiomatic expression ("me eché un chagüer") or within a gerundial construction ("estaba liqueando");

- a high density of code-mixing as a wordbuilding strategy occurring right in the middle of a word to express the grammatical gender ("troka", "traila") or to denote a peculiar Spanglish pronunciation of a word ("chimenay"; "lonche"; "mol"; "chagüer");

- other proper Spanglish features: the zero article in the attributive prepositional phrases after the preposition "de" ("de Americas"), the omission of the stress sign when this does not involve changing the meaning of a 
word/phrase ("Americas" as compared to "llegué y me bajé").

So it can be pointed out that Spanglish uses certain English and Spanish elements to create a text of its own. Spanglish-speakers blend these elements using codeswitching and code-mixing techniques alongside with new wordbuilding patters to produce a matrix of their mentality.

\subsection{Functions of Spanglish}

The new frame of thinking motivates language speakers to express various linguistic functions in their social interaction.

Like any language variety Spanglish has a set of basic functions: communicative, cognitive, emotional, intentional, metalinguistic, phatic, ideological, nominative, and esthetic functions, which are quite standard and have been thoroughly described.

As a poststandard language which aims at integrating diversity in a globalized community, Spanglish has developed some peculiar functions which can be stated as follows.

The key function of Spanglish is to demonstrate the ethnic and cultural identity of its speaker. According to A. C. Zentella, "on the periphery of a prestigious English monolingual world and the periphery of a stigmatized Spanish monolingual world... their code-switching was a way of saying that they belonged to both worlds" [19], in which they are unwilling to give up one for another world, or ethnic origin, they belong to.

Code-switching and code-mixing, being extensively used in Spanglish, allow its speaker to invent new discourse strategies. At the pragmatic level the speaker makes linguistic choices based on their "social relations, rights and obligations that exist and are created between participants in a conversation" [20].

The analysis of Spanglish texts has shown that codeswitching and code-mixing can perform a range of important functions characteristic of a conventional language:

- expressing feelings. E.g.:

OK, you can go echarle en la face.

('OK, you can throw it on the face.')

- emphasis. E.g.:

Mi nombre no es buenita, mister!

('My name is not good girl, mister!')

- being funny. E.g.:

Yo así aprendí mis vowels! A, E, I, O, U, el burro sabe más que tú!

('That's how I learned my vowels! A, E, I, O, U, the donkey knows more than you do!')

- making plans. E.g.:

El picnic se pasó para el $4^{\circ}$.

¿Por qué? Why?”

('The picnic was moved to the $4^{\text {th }}$.'

'Why?')

- requesting. E.g.:

¿Tienes una pelota? ¿Tienes pelota? Tu machine, ¿dónde está? Pues, tráela."
('Do you have a ball? Do you have a ball? Your machine, where is it? Then, bring it.')

At the same time, the above-mentioned functions of code-switching and code-mixing lead to a more important set of functions conducted by Spanglish and aiming at overcoming cultural diversity through the following conversational strategies:

- footing. E.g.:

(4) Si, Vegas. No, never mind.

('Yes, Vegas. No, never mind.')

- clarification and/or emphasis. E.g.:

(5) "...pero cuando esta el... power whatever... es así, no?" "No, no, no, no, cierto".

(' "...but when the... power whatever... is like this, right?" "No, no, no, no, correct." ')

- crutch-like code-mixing. E.g.:

(6) Pancho, guarata, you know.

('Pancho, sounds like, you know.')

- simplification/deetymologization of a unit through code-mixing. E.g.:

(7) Teikerisi.

('Take it easy.')

In (4), the speaker is playing hangman. She thinks she has guessed the word.

In (5), the speaker uses code-mixing to talk about a math problem because it is necessary to clarify a concept in this context.

In (6), the speaker uses code-mixing to introduce a sentence filler.

In (7), the form of the set expression is simplified because the speaker is unlikely to derivate the idiomatic meaning of the phrase from the meaning of the elements comprising it. So the most logical and effective way is deetymologize the phrase and use it as a word, thus creating a cultural metaphor of a blended community where the speaker is neither English or Spanish because s/he has a new Spanglish identity.

\section{Conclusion}

It can be concluded that a poststandard language is a way of integrating people, cultures, and territories, which should be closely analyzed and described from the viewpoint of linguistics as one day it could lead to the formation of a unified international language having an unprecedented political and economic impact on a global scale.

Spanglish as the most disputable linguistic phenomenon of nowadays is not just a code-switching variety. It is a new way to communicate and bring together people of different ethnic, social and political background who happen to belong to a multicultural community due to current global processes. Spanglish of the USA and Latin America performs both conventional and innovative functions, and its most peculiar feature is believed to be a new conversational strategy aimed at bridging the diverse society.

Finally, it should be accepted that a poststandard language which incorporates elements of both source languages through the extensive use of code-switching 
and code-mixing is a unique variety which is certainly able to develop its own units and enrich global culture.

\section{References}

1. D. Cameron, New Media Language, 27-35 (Routledge, New York, 2004)

2. T. McArthur, Language Teaching 34, 1-20 (2001)

3. M. Montgomery, Language Myths, 66-76 (Hardmondsworth, 1998)

4. S. G. Thomason and T. Kaufman, Language Contact, Creolization, and Genetic Linguistics (University of California Press, Berkeley, 1988)

5. J. Dunn, Rusistica, 1-2, 27-36 (1998)

6. Á. López García-Molins, Teoría del Spanglish (Tirant Humanidades, Valencia, 2015)

7. S. Betti, Glosas, 5-14 (August 8, 2015)

8. O. A. Santa Ana, Hisp. J. of Behav. Sc. 15 (1), 3-35 (1993)

9. G. Tottie, An Introduction to American English (Blackwell Publishers, Oxford, 2002)

10. S. Butler, English in an Asian Language: The Philippine Context, 103-124 (Macquarie Library Pty Ltd., Sydney, 1997)

11. I. Stavans, Spanglish: The Making of the New American Language. (HarperCollins Publishers, New York, 2003)

12. B. Cruz and B. Teck, The Official Spanglish Dictionary (Simon \& Schuster, New York, 1998)

13. E. Morales, Living in Spanglish: The Search for Latino Identity in America (St. Martin's Press, New York, 2002)

14. I. Stavans, World Literature Today 74, 555-558 (2000)

15. J. C. Franco and T. Solorio, UTEP Depart. Tech. Rep. (January 1, 2007)

16. N. Sokol, Lexicomania, 122-142 (The University of Wisconsin Press, Madison, 2004)

17. J. J. Gumperz, Contextualization Conventions: Discourse Strategies. Studies in Interactional Sociolinguistics 1 (Cambridge University Press, Cambridge, 1982)

18. L. M. Orsi, Informal Social Interactions (Hamline University, Saint Paul, 2008)

19. A. C. Zentella, Growing up Bilingual: Puerto Rican Children in New York (Blackwell, New York, 1997)

20. S. Romaine, Bilingualism (Basil Blackwell, Oxford, 1989) 